\title{
Gáspár Andrea
}

\section{A személyi jövedelemadó rendszerének alakulása Magyarországon (1988-2014)}

Andrea Gáspár: Changes in the personal income tax system in Hungary (1988-2014)

\begin{abstract}
Since its introduction, the Hungarian income tax system has been going through a continuous restructuring process. In my analysis I examine the main changes which have occurred in the Hungarian personal income tax system from the 1990 s to the present day. I have also made a short international detour regarding the flat tax system as it seems that global trends also favor simplification. Flat-rate tax might interfere with the tax principle of equity, but it can ease verifiability and the declaration of income for tax return and might help to decrease tax administration costs and tax evasion. The most successful reforms which resulted in the improvement of tax morale, transparency and increased tax receipts were the ones which involved the reduction of benefits and exemptions. I have examined how the annual changes in the personal income tax system will affect the tax burden of private entities.
\end{abstract}

Keywords: PIT, tax breaks, tax rates, tax

\section{ÖSSZEFOGLALÓ}

A magyar adórendszer mindenkit érintő része a személyi jövedelemadó - folyamatos átalakításon esett át a bevezetése óta. Elemzésemben a direkt adó csoportjába sorolt adónemben bekövetkezett fóbb változásokat vizsgáltam a kilencvenes évektől napjainkig. A 2011. évben bevezetett egykulcsos adórendszerrel kapcsolatban kis kitérőt tettem nemzetközi téren, hiszen a nemzetközi trendek az egyszerűsítés felé mutatnak. Az egykulcsos adó sértheti ugyan az igazságosságot, mint adózási elvet, de megkönnyítheti az ellenőrizhetőséget, az adóbevallást, és csökkentheti az adóadminisztrációs költségeket valamint az adóelkerülést. Arra kerestem a választ, hogy a minden évben bekövetkezó személyi jövedelemadó változtatás, főképp az adókedvezmények és kivételek mérséklése, valamint az adókulcsok csökkentése, milyen hatással bírt a magánszemélyek adóterhére.

Kulcsszavak: Szja, adókedvezmények, adókulcsok, adó

\section{BEVEZETÉS}

Az államháztartás bevételei közül nagyságrendjük és a gazdaságot érintő hatásuk szerint is a legjelentősebbek az adók és járulékok. $A z$ adó - legáltalánosabban megfogalmazva - kötelező jellegű, vissza nem térülő, visszafizetés nélküli, általános, pénzbeli szolgáltatás, amelyet az állam vagy más közhatalmi szervezet olyan jogszabályok alapján hajt be, mely ezen kötelezettségek nagyságát, fizetés esedékességét és feltételeit egyaránt meghatározzák. (Kállai, 2000) A személyi jövedelemadó az adórendszer részeként a klasszikus állami funkció szempontjából fontos eszköz.

A mai magyar adórendszer kialakulása az 1988ban történt adóreformmal kezdődött. (Kállai, 2000) 1988 óta az adórendszer szabályozása Magyarországon a fejlett országok gyakorlatát követi. Hozzáadott érték adó (ÁFA), jövedelemadók kerültek bevezetésre a vállalatok, egyéni vállalkozások, és 
magánszemélyek részére egyaránt. $A z$ adóztatás súlypontja a termelést terheló adókról folyamatosan a fogyasztást terheló adókra, a jövedelemadókon belül a munkajövedelmekre helyeződött át. (Deák, 1997)

Az 1988. évet követő időszakban folyamatosan új adók jelentek meg. 1995. évben eltérő gyakorisággal és mértékben, de összességében 53 jogcímen kellett adót, illetéket, vámot, járulékokat fizetni. Az állandó változások csak még jobban nehezítették az áttekinthetőséget. (Pitti, 1996)

Ötödik nagy adónemként 1998-ban bevezetésre került a jövedéki adó Magyarországon. Az 1999. évben közel hetvenféle adónyomtatvány és további húszféle járulékkal kapcsolatos bejelentési, változásbejelentési nyomtatvány volt használatos. (Ilonka, 2004)

Az adórendszer egészét érintő változás volt a 2003. évben bevezetett EVA, ami mérsékelte a kisvállalkozások adóterheit, és jelentősen csökkentette számukra az adórendszer szabályainak betartásával kapcsolatos költségeket és minden tekintetben jelentősen megkönnyítette adminisztrációjukat. (Semjén, 2006)

Ugyancsak a vállalkozások adminisztrációs terheinek csökkentéséhez járult hozzá a 2005. évben bevezetett Egyszerúsített közteherviselési hozzájárulás (EKHO) is. Ezt az adónemet csak bizonyos foglalkozást végző magánszemély választhatja meghatározott árbevétel alatt. (Herich, 2007)

Egyre több adó jelent meg Magyarországon. 2010-ben 5 darab (pl. Végkielégítések 98\%-os különadója), 2011. évben 6 darab (pl: Népegészségügyi termékadó), 2012-ben 17 darab (például: Szociális hozzájárulási adó, Baleseti adó) új adónem került bevezetésre.

2013. évben két új adónemmel lett több Magyarországon. Az egyik a kisadózók tételes adója (KATA) a másik a kisvállalkozói adó (KIVA). A KATA meghatározott vállalkozási formák választhatják, bármikor akár év közben is választható és ki is lehet lépni belőle, de akkor visszalépés 2 évig nem lehetséges. Előnyösebb az EVA-nál. A KIVA szélesebb körben használható, mint a KATA, viszont jóval szerényebb kedvezményeket nyújt a vállalkozások számára.

2014. évben a Reklámadó került bevezetésre, többek között a médiaszolgáltatók adóterhét emelheti meg, mely alapján a nettó árbevételük meghatározott \%-át kell ilyen jogcímen az állami adóhatóság felé befizetniük.

A személyi jövedelemadó fóbb változásai Magyarországon

$\mathrm{Az}$ 1988. évi adóreform során bevezették a magánszemélyek jövedelemadóját és ezzel a lakosság nagy része adóalannyá vált, a lakossági jövedelmek egységes adóztatása Magyarországon ekkortól valósult meg, hiszen ezt megelőzően a magánszemélyt jövedelme után csak bizonyos esetekben terhelte adófizetés. (Kállai, 2000)

Minden évben - és most már sajnos év közben is - megváltoztatják a lakosság legnagyobb részét érintő adótörvényeket, többek között a Szja-ra vonatkozó jogszabályokat. Mindez az előre tervezhetőséget, a stabilitást csökkenti és így nagyfokú bizonytalanságot okoz az adózókban.

A következő évek változtatásai 1994-ig a személyi jövedelemadóban a következők voltak:

- emelkedtek a sávhatárok,

- a fokozódó infláció miatt folyamatosan, már 1990-ben a legfelső kulcs 60 százalékról 56 százalékra csökkent, ami ugyan mérsékelte a progressziót, viszont a legjobban kereső rétegek a korábban bérbruttósításként kapott összeg egy részét megtarthatták. Már 1994-re egy hatkulcsos adótáblázat maradt a korábbi 11 kulcsos helyett, 110000 forintig adómentes jövedelemhatárral, a legfelső 
sáv határadókulcsa 44\%-ra mérséklődött 60\%-ról,

- az adóteher növekedett.

1998-ra egy, az 1988-as adóreformtól gyökeresen különböző szja rendszer lépett életbe, amely a méltányosság és igazságosság addig preferált szempontjai helyett a hatékonyságot helyezte előtérbe, nem utolsósorban a fokozódó ellenőrzések révén is.

A kialakult adórendszer:

- figyelmen kívül hagyta a szociális szempontokat, a szociálpolitikára hagyva a méltányosság és igazságosság eleinek érvényesítését,

- differenciált a jövedelmek között azok forrása szerint,

- preferálta a tőkejövedelmeket,

- összekötötte a jövedelemadót a tb elvonásokkal a béreken túl is.

A 2000. évektől folyamatos változtatások léptek életbe a szja törvényben, melyeket a vizsgálatom Eredmények részénél külön kiemelek. Lényeges változás a kedvezmények számának lecsökkentése, az adókulcsok számának mérséklése, egy kulcsossá tétele, a családi adózás bevezetése, mely véleményem szerint csak nevében családi adózás.

\section{Egykulcsos adórendszer}

A XIX. századig az iparilag fejlett társadalmakban az egykulcsos adórendszer volt az általános. Mára a legfejlettebb országok mindegyike sávos adózási rendszert használ, és bár viták vannak, nincs jel arra, hogy a rendszereiken változtatni szándékoznának.

A sávos adózás hívei szerint a rendszer az egykulcsos adózásnál a társadalmi teherviselés szempontjából igazságosabb, úgy vélik, hogy a progresszivitás ellensúlyozza a magasabb jövedelmúek nagyobbnak vélt adócsalási tömegét.

Az adózási sávok számának és a sávok közötti különbségek csökkentése a 80-as években felvetette az egykulcsos adózás vizsgálatának szükségességét. Az egykulcsos adózás minden jövedelmet adóztatni kíván, az adó mértékét egységesen szabja meg, azonban arra is hangsúlyt fektet, hogy a jövedelmek kizárólag egyszer kerüljenek adóztatásra. Az osztalékot és hasonló bevételek nem képezik az adó tárgyát, hiszen azokat már a társasági adózás szintjén adóztatták. Az egykulcsos adózás teljesen leegyszerúsíti a teherviselés rendszerét, átláthatóságot biztosít, nagymértékben csökkenti a torzításokat.

Az egykulcsos adózás nem csupán a személyi jövedelemadó egykulcsosságát jelentheti, hanem azt is, hogy a társasági adó szintjét az szja mértékéhez igazítják. Az adók uniformizálása teljes mértékben egyenrangúvá teszi a jövedelmeket azok forrásától függetlenül. Az egykulcsos adózás bevezetői a gazdaság élénkülését, a bürokrácia leépülését, a költségvetési bevételek növekedését, munkaösztönzést, a beruházási kedv élénkülését, a megtakarítások növekedését remélik.

A különböző jövedelmek közös adóztatásának elvét tükrözi az egykulcsos adórendszer. Az OECD (2006) négyféle egykulcsos adórendszert különböztet meg:

- egykulcsos rendszer adómentesség nélkül (Grúzia),

- egykulcsos rendszer adómentességgel (Oroszország),

- egykulcsos rendszer adójóváírással (Szlovákia), és a

- társasági jövedelmekre is kiterjedő egységes kulcs rendszert (Románia). (HallRabushka, 1995)

A világ 202 önálló országa illetve adóhatósága közül 2008-ig 21-ben volt egységes, egykulcsos személyi jövedelemadó, és ezek közül 17 egykori szocialista ország - Bulgária, Albánia, Csehország, Észtország, Grúzia, Kazahsztán, Kirgízia, Lettország, Litvánia, Macedónia, Mongólia, Montenegró, Románia, Oroszország, Szerbia, Szlovákia és Ukrajna - amelyek az utóbbi években tértek át erre módszerre, utoljára Csehország.

Egykulcsos adórendszert több Uniós tagországban alkalmaznak, pl: Románia, 
Bulgária, Csehország, Szlovákia, Észtország, Lettország, Litvánia és 2011-től Magyarország is.

Az egyszerűség, a hatékony ellenőrzés, valamint az alacsony adminisztráció miatt az „egykulcsos” adórendszerek elterjedtté váltak a közép-kelet-európai országokban. Az ilyen reformok jelentősen csökkentik a személyi jövedelemadó szintjét, és gyakran növelik a jövedelemegyenlötlenségeket. (Bakos et al., 2008)

Az 1980-as évek elején Hall és Rabushka (1995) kidolgozott egy egykulcsos adórendszerre vonatkozó javaslatot, amelyben minden egyes dollár jövedelem 19\%-os egységes kulccsal adózik, kivéve a családok 25 ezer USD alatti jövedelme, ami adómentes. Érveik szerint ez az egyszerű adórendszer jelentősen hozzájárul a gazdasági növekedéshez, mivel számottevő adminisztrációs költséget takarít meg. Rabushka (2006) szerint egy ilyen rendszerben gyakorlatilag nincs szükség adóbevallásra, mivel minden egység jövedelem keletkezésekor automatikusan le lehetne vonni az egységes adót, megtakarítva így az adó kiszámítását, bevallását, jelentősen leegyszerúsítve az ellenőrzést, és megszüntetve az adórendszeren belüli arbitrázs-helyzeteket.

Az egykulcsos adórendszerektől három területen lehet jelentős hatást várni:

1. az alacsonyabb határadókulcsok növelhetik a munkakínálatot, ami az adóalap megnövekedését is eredményezheti,

2. az alacsonyabb határadókulcs kisebb ösztönzést jelent az adóelkerülésre, így javulhat az adóbevallás és befizetés, ezáltal a költségvetés több bevételhez jut,

3. az adórendszer egyszerűsítése, ami az adóadminisztrációs költségek és az adóelkerülés csökkenését egyaránt segíti.

$\mathrm{Az}$ egykulcsos adórendszer bevezetése a legtöbb esetben nem azért vált előnyőssé, mert egységes adókulcsot biztosított, hanem mert a korábbi kedvezmények, kivételek megszüntetése következtében lehetőséget nyitott az adóadminisztráció egyszerűsítésére, és az adóalap szélesítésére.

További, közvetett hatás, ha az egykulcsos adó bevezetése okán nőhet az ország tőkevonzó képessége. Az egykulcsos adórendszer legfőbb hátrányaként szokták említeni, hogy növeli a jövedelmi egyenlőtlenséget. (Bakos et al., 2008)

Saavedra (2007) arra a következtetésre jutott, hogy a reformok akkor javítják az adómorált, ha a reform egyúttal az adóadminisztráció egyszerúsítésével is jár, ugyanakkor az állami bevételekre gyakorolt növelő hatás szignifikanciája nem volt kimutatható. $A z$ adóelkerülés azokban az országokban csökkent, amelyekben az szja-kulcs és a társasági nyereségadó kulcsa megegyezett (tehát közelebb álltak a klasszikus egykulcsos rendszerhez).

Az egykulcsos adók bevezetésével kapcsolatos tanulságokat összegezve Saavedra (2007) kiemelte, hogy az adókulcsok csökkentését is tartalmazó reformok esetén csak úgy kerülhető el a bevételek csökkenése, ha a jövedelemadó rendszerében sikerül bezárni a kiskapukat és megszüntetni a sokféle kedvezményt és kivételt. Az adómorál javulása, az áttekinthetőség és a bevételek tekintetében azok a reformok sikeresnek, ahol a kedvezményeket lecsökkentették. További tanulság, hogy az szja adóalap növelése és az szja-bevallási hajlandóság érdemi javulása csak akkor várható, ha a reformok kiterjednek a társadalombiztosítás rendszerre is. A tb és az szja adóalapja ugyanis a legtöbb országban majdnem azonos, így a magas marginális kulcsú tb fizetési kötelezettség erős ösztönzést ad a kisebb adóalap bevallására (hiába csökken az szja-kulcs).

Az egykulcsos jövedelemadó a differenciált és progressziv adókulcsokhoz képest kisebb mértékben terheli a gazdagok jövedelmét, a szegényekét viszont nagyobb mértékben. Ezért az egykulcsos adó Erdős (2006) véleménye szerint csak akkor vezethető be, ha ennek 
megfelelően az alsó jövedelmi tizedekhez tartozók valamilyen formában kiegészítést kapnak. Így, az egykulcsos adó bevezetése mellett, bizonyos jövedelemhatár alatt adómentességet kell biztosítani.

Vagy, az alsó tizedekben negatív adóztatást kell alkalmazni, ha a cél az, hogy a tényleges jövedelem valamilyen legkisebbnek ítélt szint alá semmiképpen ne csökkenjen.

Benedek és Lelkes (2006) munkájukban mikroszimulációs modell segítségével vizsgálták a magyarországi egykulcsos adórendszer bevezetésének hatásait. A szlovák adóreform során bevezetett adórendszerhez némiképpen hasonló, a jelenlegi magyar szabályozásnál egyszerúbb adórendszert vizsgáltak: az adókulcsok egységesen 20 százalékosak, minden jövedelem az összevont adóalapba tartozik, de megmarad a minimálbér adómentességét biztosító adójóváírás és kiegészítő adójóváírás. Ezen kívül nincsen más adókedvezmény, támogatás. Ez az elképzelés csökkentené az adórendszer komplexitását, így növelné az átláthatóságát. Számításaik szerint egy ilyen egykulcsos adórendszer bevezetése elsősorban a gazdagabb háztartásoknak kedvezne, és a szegényebb családok lennének a vesztesei. Ennek elsődleges oka a felső adókulcs csökkentése lenne. Az egységes kulcs esetén a jövedelmek tőke- vagy munkajövedelmek közötti átcsoportosításával nem lehetne adót kerülni. Ebben az esetben az ellenőrzés könnyebbé válna, ami az átláthatóságot növelné.

\section{ANYAG ÉS MÓDSZER}

A kutatás során az adóhatósághoz (NAV) hibátlanul benyújtott összevont adót tartalmazó személyi jövedelemadó bevallások adatai (1995-2012), valamint a hatályos adójogszabályok (1988-2014) felhasználásával végeztem el. Az időintervallum szélessége folytán volt olyan időszak, melynél nem álltak rendelkezésemre adatok, így az adatok vizsgálatát kisebb időszakra kellett elvégeznem. $\mathrm{Az}$ adatok összevontak, egyedileg be nem azonosíthatóak, így adótitkot nem sértenek.
A rendelkezésre álló adatok felhasználásával különböző matematikai és statisztikai mutatószámok (megoszlások, arányok, változások vizsgálata) segítségével vontam le a következtetéseimet a magyar személyi jövedelemadó rendszer változtatását illetően. Vizsgálatom során csak az összevont adóalap elemzését végeztem el. Nem tértem ki az egyéni vállalkozók adóterhének, valamint a költségszerkezet és a bevétel elemzésére. Az adófizetési hajlandóság és az adókulcsok mértéke közötti kapcsolatot sem vizsgáltam.

\section{EREDMÉNYEK}

A GDP-hez mért adóbefizetések mértéke 37\% és $42 \%$ között ingadoztak az általam vizsgált években. A legalacsonyabb 2011. évben $(37,1 \%)$ a legmagasabb pedig 1995. évben $(41,5 \%)$ volt. (1. ábra).

A magyar adórendszer egyik legtöbb teljesítmény-visszatartó vonással rendelkező eleme az szja. Ez az egyik legfontosabb, a lakosság széles körét érintő direkt adónem, melynek az összes NAV által kezelt adóbevételeken belüli megoszlása 1998. évben volt a legmagasabb $34 \%$, a legalacsonyabb pedig 2012. évben volt, akkor $14 \%$-ot tett ki (2. ábra) az összes adón belül ez az adónem.

A GDP-hez mért személyi jövedelemadó-teher mértéke $5 \%$ és $8 \%$ között erőteljes hullámzást mutat. 2011. évben többek között az egykulcsos, családi személyi jövedelemadó rendszerének bevezetése miatt alig érte el az 5\%-ot (3. ábra).

Sajátossága volt a személyi jövedelemadó rendszernek, hogy 2010. évig az adósávok szűkek voltak, és alig volt eltérés az alsó és a felső adókulccsal adóztatott jövedelmek között. $\mathrm{Az}$ adóalap szúk, mert kedvezményekkel, kivételekkel volt teletűzdelve. Ezen kettősség következményeként nagy rés tátongott a törvényi és a tényleges, effektív adóterhelés között a széleskörű kedvezmények miatt. A személyi jövedelemadó-rendszerben sérül a horizontális és a vertikális méltányosság elve. (Gáspár et al., 2004) 
Az adókulcsok száma 1988 és 2014 között folyamatosan csökkent (1. táblázat), mely az egyszerúsítés, átláthatóság irányába mutat.
Továbbá a 2011. évben bevezetett egykulcsos adórendszer ezt még jobban erősíti.

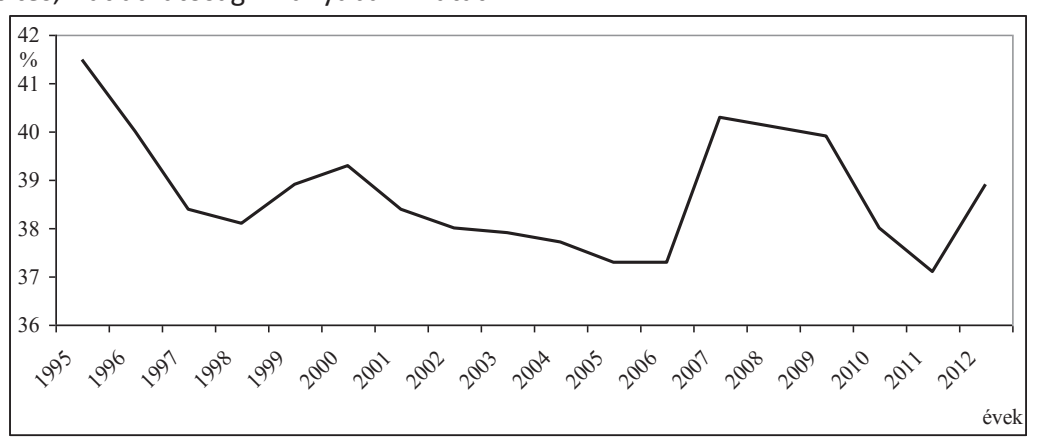

1. ábra Az összes befizetett adó alakulása a GDP százalékában 1995-2012 között Forrás: OECD statisztikai jelentése saját szerkesztés

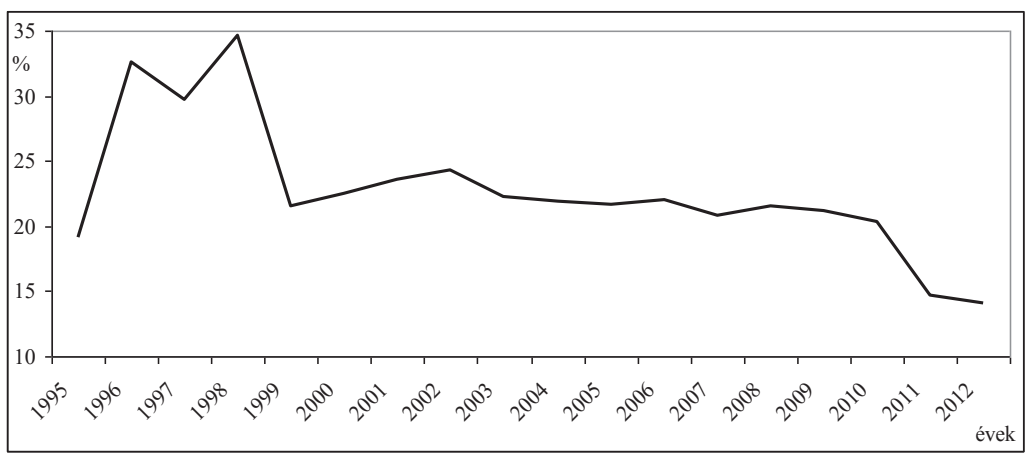

2. ábra: 1995-2012 között a személyi jövedelemadó megoszlása az összes adóbevételen belül Magyarországon

Forrás: NAV Évkönyvek alapján saját számítás és szerkesztés

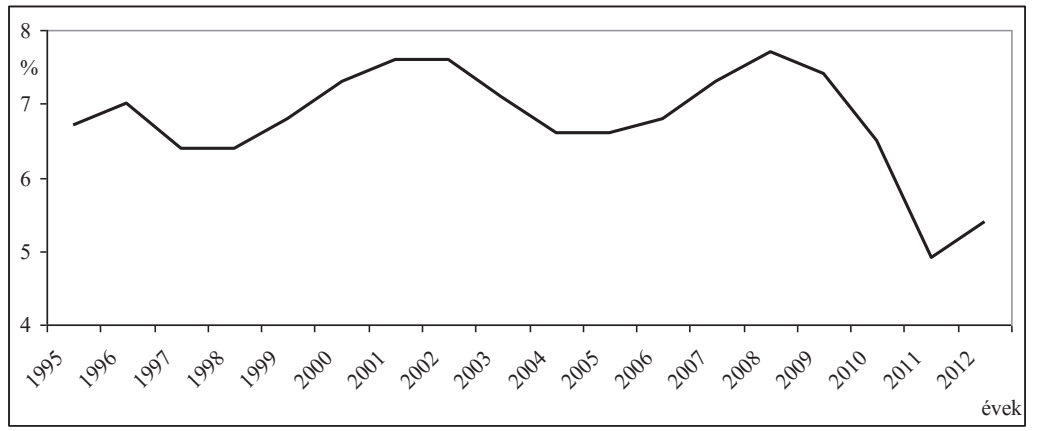

3. ábra A személyi jövedelemadó alakulása a GDP százalékában 1995-2012 között Forrás: OECD statisztikai jelentése saját szerkesztés 
Alkalmazott kutatások eredményei a gazdaság- és társadalomtudományok területén

\begin{tabular}{|c|c|c|c|c|c|c|c|c|c|}
\hline Évek & 1988 & 1989 & 1990 & 1991 & $\begin{array}{c}1992- \\
1993\end{array}$ & $\begin{array}{c}1994- \\
1998\end{array}$ & $\begin{array}{c}1999- \\
2004\end{array}$ & $\begin{array}{c}2005- \\
2010\end{array}$ & $\begin{array}{c}2011- \\
2014\end{array}$ \\
\hline Adókulcsok száma (db) & 11 & 8 & 5 & 7 & 4 & 6 & 3 & 2 & 1 \\
\hline
\end{tabular}

1. táblázat: Progresszív jövedelemadó kulcsok számának alakulása Magyarországon 1988-2014 között

Forrás: saját kigyüjtés alapján saját szerkesztés

Az szja sávosan progresszív volt, a legkisebb és legmagasabb adókulcsa, mely az összevonás alá tartozó jövedelmeket sújtja, 1988 és 2010 között egyre jobban közeledett egymáshoz, 1988-ban a $0 \%$ és $60 \%$ 2010-ben $17 \%$-ra és $32 \%$-ra változott. 2011. évtól (jelenleg is) egy kulcs (16\%) van érvényben. (4. ábra).

Magyarországon a sávosan progresszív adótáblázat eltérő kulcsaihoz eltérő sávhatárok tartoztak. 1988. évben a legkisebb adókulcs 48 ezer Ft-os sávhatára 2009-re 1.900 ezerre, majd 2010-re 5.000 ezer Ft-ra emelkedett (5. ábra). A legmagasabb adókulcs sávhatára 1988-ban 800 ezer Ft-ról 2009-re 1.900 ezerre, 2010-re pedig 5.000 ezer Ft-ra nőtt. 2011. évre egykulcsossá vált az szja rendszer. $A z$ szja sávosan progresszív adókulcsa 2005. évben kétsávossá vált, így a legkisebb adókulcs felső sávhatára megegyezett a legmagasabb adókulcs sávhatárának értékével. 2004-ben az adózás rendjéről szóló törvény (Art) új adó-megállapítási módot honosított meg a személyi jövedelemadózásban: az adóhatósági adó-megállapítás rendszerét. Az adózó dönti el, hogy választja-e persze bizonyos feltételek teljesülése mellett. Ezzel a magánszemélyek egy része nem saját maga tölti ki és juttatja el adóbevallását az illetékes adóhatóságnak, hanem ezt az adóhatóság teszi meg, az adózóval szoros együttmúködésben. Ez az adóadminisztrációs terhek csökkentését hozta magával, bizonyos adózói körben. De pont ott volt egyszerűsödés, ahol csak egy adóbevallási határidőhöz kell alkalmazkodni. Véleményem szerint ez a megoldás csak részben járult hozzá az egyszerüsítéshez. Főleg, ha még azt is figyelembe vesszük, hogy az önbevallók aránya 1995-ben 52\%-ról 2012-ben 84\%-ra emelkedett (6. ábra).

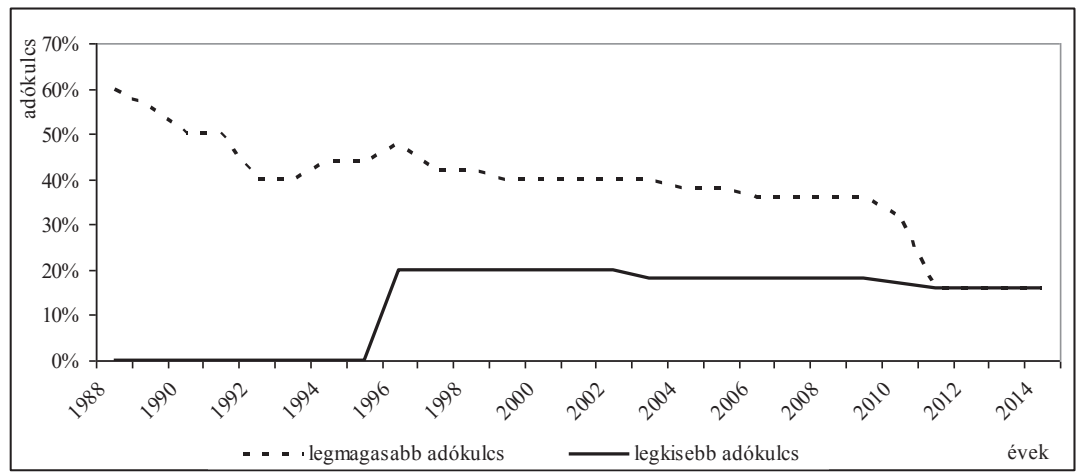

4. ábra: 1988-2014 között a legkisebb és a legnagyobb szja kulcs alakulása Magyarországon

Forrás: Hatályos Szja törvény alapján saját szerkesztés 


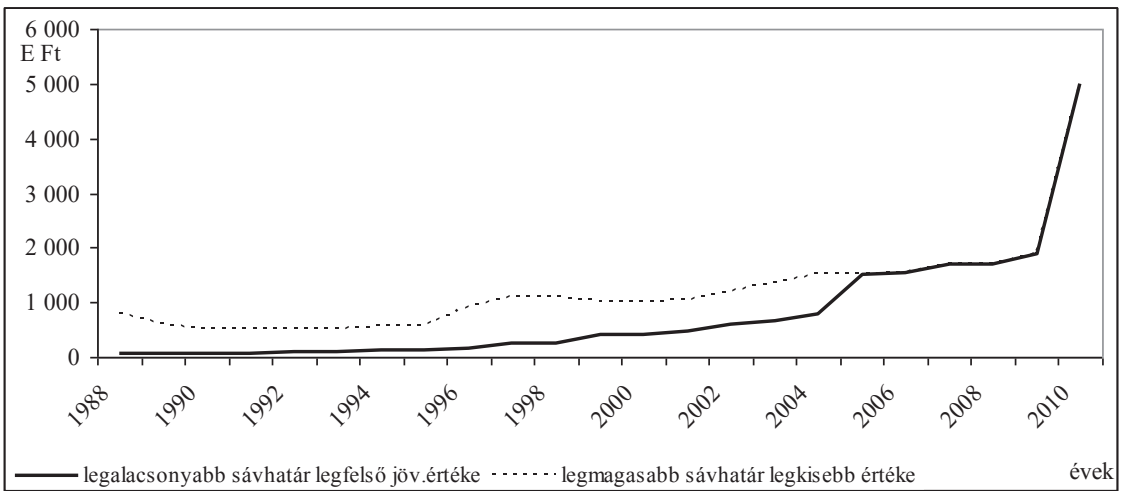

5. ábra: 1988-2010 között a legkisebb és a legmagasabb adókulcs sávhatárainak alakulása Forrás: A hatályos szja törvény alapján saját szerkesztés

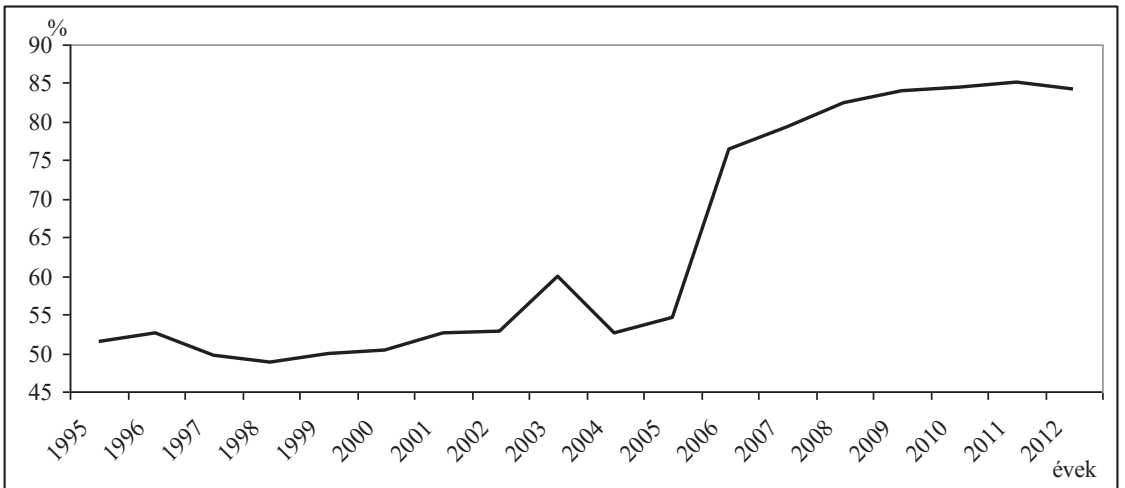

6. ábra: 1995-2012 között az önbevallók arányának alakulása

Forrás: A NAVÉvkönyvek alapján saját szerkesztés

Véleményem szerint ez 2014. évben tovább emelkedik majd, hiszen mindenkinek lesz lehetősége a már elküldött bevallás önellenőrzését az adóbevallás benyújtási határideje előtt is elvégezni. Ez most még csak a határidő lejárta után lehetséges még.

Az adókedvezmények száma 1998 évben tizennégy jogcím volt, mely 2008-ra huszonháromra emelkedett, majd 2009-re tizenkilencre csökkent, majd a kedvezmények nagy része kivezetésre került 2011. évtől (pl: lakáscélú hiteltörlesztés, személyi kedvezmények), de egy nagyon fontos kedvezmény került bevezetésre, mégpedig a családi kedvezmény. $\mathrm{Az}$ igénybevett adókedvezmények összegének aránya az adóhoz képest folyamatosan, évről évre változott (7. ábra). Ez az arány 1994-ben 6,8\%ról 2009-re 24,5\%-ra emelkedett, majd 2012ben az $1 \%$-ot sem érte el.

A személyi jövedelemadó adóterhe 1995-ben $21 \%$ volt, mely 2012 . évben $15 \%$ lett (8. ábra). A legmarkánsabb csökkenés a 2011. évben volt, amikor a bevezetett egykulcsos családi adórendszer következtében $15 \%$ alá csökkent a mutató értéke. 
Alkalmazott kutatások eredményei a gazdaság- és társadalomtudományok területén

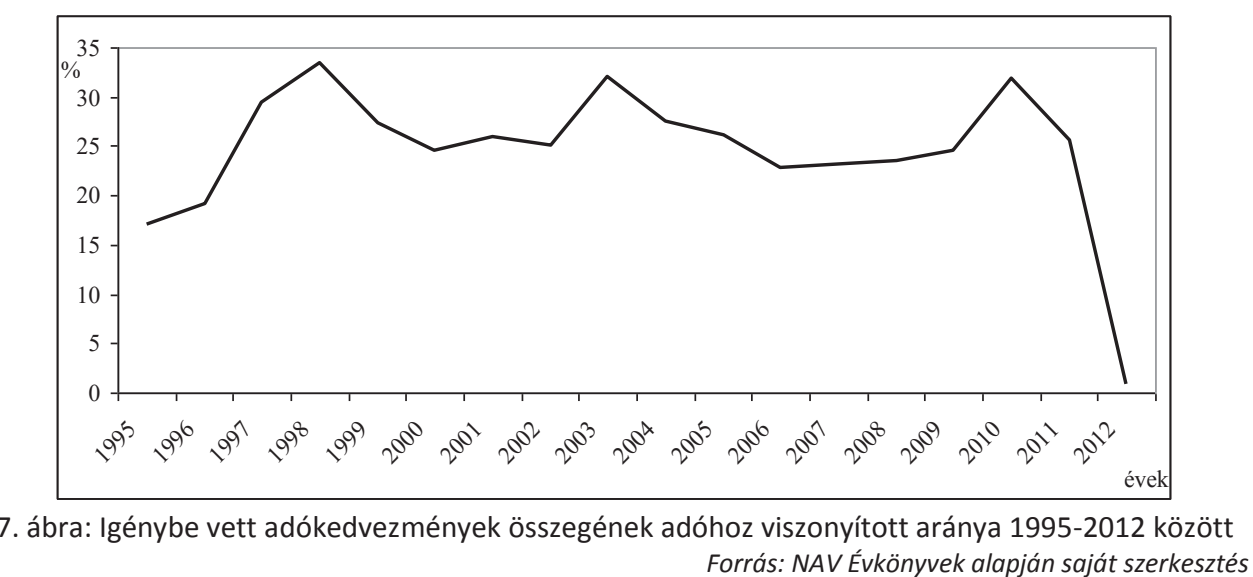

Forrás: NAV Evkönyvek alapján saját szerkesztés

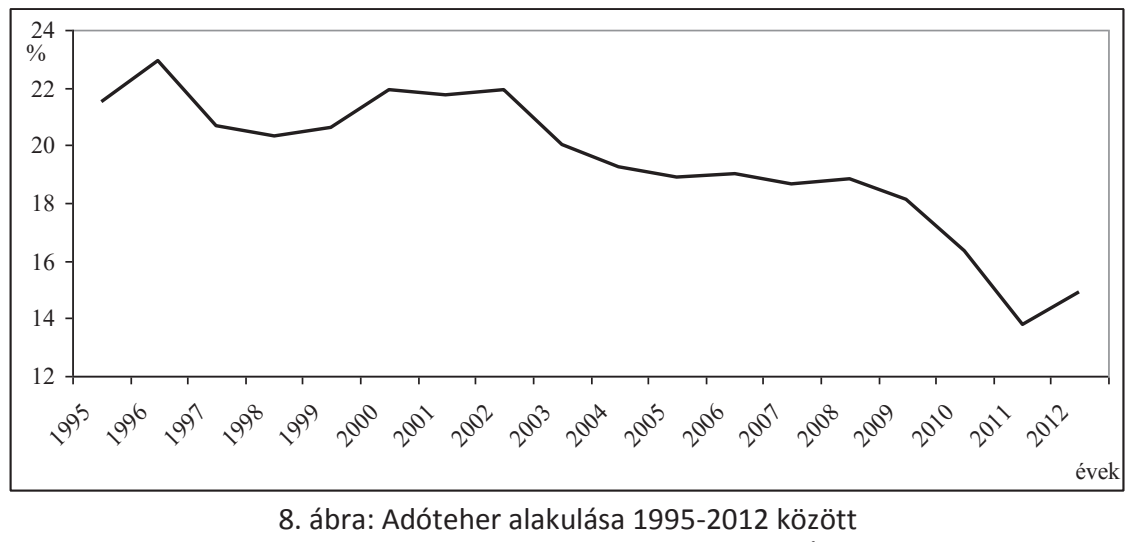

Forrás: NAV Évkönyvek alapján saját szerkesztés

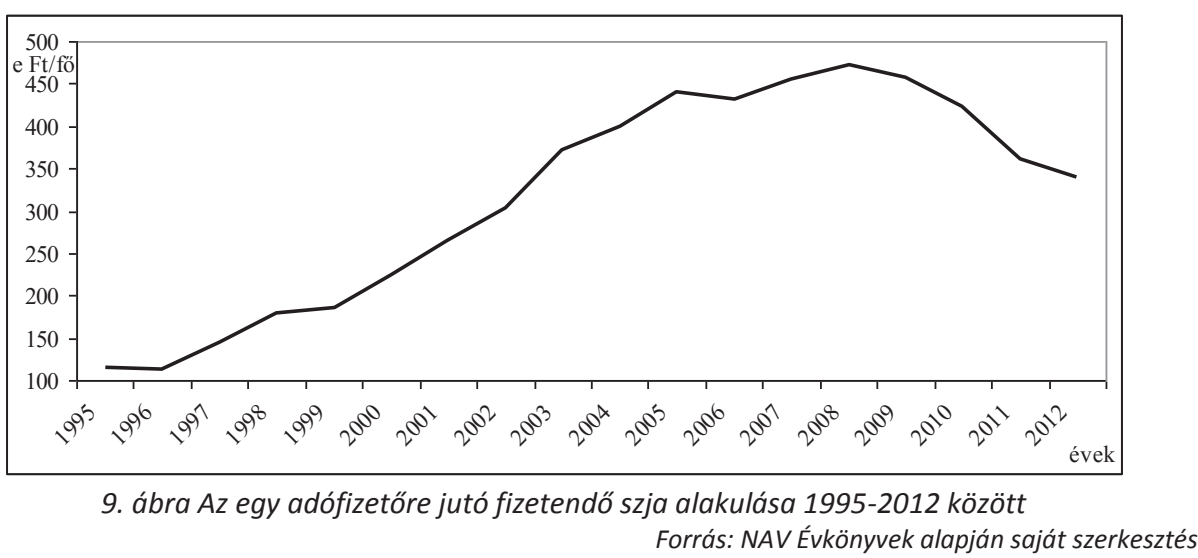

ECONOMICA 2014 2. szám

$(31)$ 


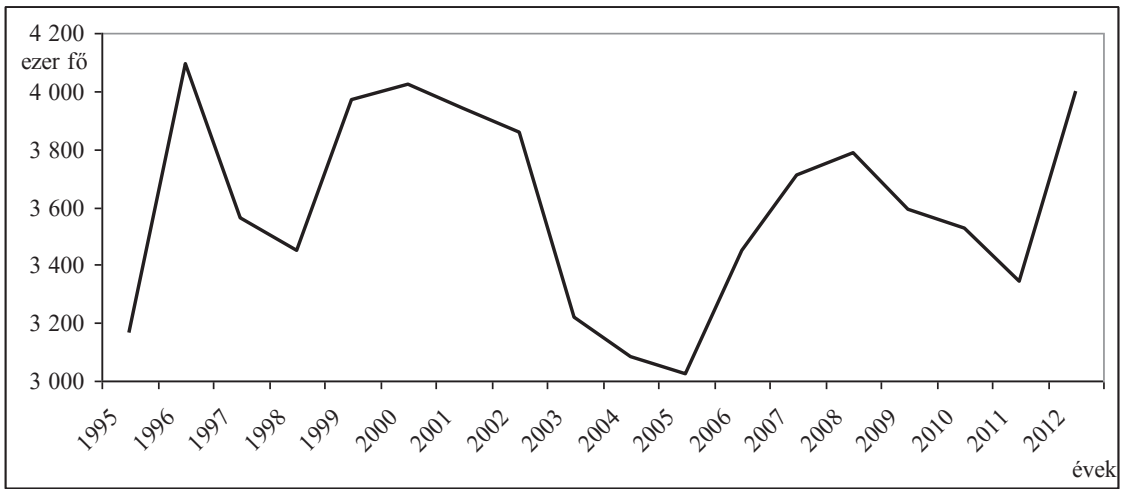

10. ábra A személyi jövedelemadót fizetők számának változása 1998-2012 között

Forrás: NAV Évkönyvek alapján saját szerkesztés

1999-ben az szja korábban öt kulcsos sávosan progresszív adórendszere 2005. évre két kulcsos, majd 2011-ben egykulcsossá vált, ám az adójóváírás csökkentése, 2012. évben történő kivezetése, az adótáblázat változtatása az adóterhelést is módosította. Az egy adófizetőre jutó fizetendő adó szinte minden vizsgált évben emelkedett2008. évig, ahol elérve a maximumot ( $473 \mathrm{E} \mathrm{Ft/fó)} \mathrm{folyamatosan}$ lecsökkent 2012-ben 339 E Ft/fö értékre (9. ábra).

A személyi jövedelemadót fizetők számának alakulása 1995 és 2012 között erőteljes hullámzást mutat. (10. ábra) A legalacsonyabb 2005-ben volt 3.026 ezer fö, a legtöbben 1996évben vallottak szja-t közel 4.100 ezren.

\section{KÖVETKEZTETÉSEK, JAVASLATOK}

Súlyos problémát jelent a szerkezetből fakadó vállalati adminisztrációs teher, a járulék- és adónemek magas száma, az egyes adók egyenkénti befizetése, az adó kiszámítása és bevallása jelentős időráfordítást és szakértői költséget emészt fel, tehát összességében feleslegesen bonyolult. A Világbank által végzett felmérés szerint a magyar adórendszer 2008-ban csupán a világrangsor 127. helyén állt az egyszerúség terén. (PWC, 2008).

A mostani magyar adórendszer egyik fó problémája a szerteágazóság, a bonyolultság a kedvezmények sokszínűsége. Ezen jellemzők megszüntetésével, melyre már történtek kedvező lépések, a jogkövető magatartást elősegítheti, és stabil fiskális környezetben pozitív hatással lenne a magyar gazdaságra.

A magyar adórendszer megérett egy átfogó változtatásra. A kedvezmények, kivételek sokasága, valamint a sorozatos változtatás az átláthatóságot és az előre tervezhetőséget akadályozza.

Nemzetközi tapasztalatok alapján kijelenthetjük, hogy az egyszerüsítés eredményre vezethet, a fent említett feltételek teljesülése esetén.

Az egykulcsos adó kedvező hatása lehet, hogy javítja a versenyképességet, növeli a fogyasztást és hozzájárul a gazdasági növekedéshez. Hátránya viszont, hogy a magasabb keresetúek a korábbihoz képest kevesebb adót fizetnek, így az szja-ból származó adóbevételek csökkenhetnek. Ezt a hatást ellensúlyozhatja az adófizetési morál javulása (aminek vizsgálata nem volt a kutatásom célja), azonban ez országonként és reformonként változhat.

Az egykulcsos személyi jövedelemadó rendszer magyarországi bevezetése abban az esetben eredményes, ha: 
- a kedvezmények, kivételek, adóalap és adó csökkentő tételek megszüntetésre kerülnek, mert az egykulcsosnak csak ebben a formában van létjogosultsága. Ellenkező esetben csak a nevében lesz a szja rendszer egykulcsos.

- az ellenőrzési rendszer megerősítése, a végrehajtott ellenőrzések és a lehetséges büntetési tételek megnövelése, mely a kényszerítő erejüknél fogva az un. „kiskapuk” (kedvezmények) megszüntetésével, jelentős költségvetési bevételt jelentenének.

Még nem bizonyított, hogy a Magyarországon 2011. évben bevezetésre kerülő egykulcsos családi adózás önmagában érdemben ösztönzőleg hat a gyermekvállalási kedvre. Ez egy további kutatásnak lehet majd a központi kérdése.

\section{FELHASZNÁLT IRODALOM}

[1.] Bakos Péter - Bíró Anikó - Elek Péter - Scharle Ágota (2008): A magyar adórendszer hatékonysága. Közpénzügy Füzetek 21. Budapest 2008. április, pp 1-32

[2.] Benedek Dóra - Lelkes Orsolya (2006): A magyarországi jövedelem-újraelosztás és egy egykulcsos adóreform vizsgálata mikroszimulációs modellel. Közgazdasági Szemle. LIII. évf. pp 604-623

[3.] Deák Dániel (1997): Igazságos-e a magyar adórendszer? (Egy törvényhozási csapdahelyzet elemzése). Polvax: társadalomtudományi folyóirat, 1. évf. 2. sz. pp 1-11

[4.] Erdős Tibor (2006): Adózás, megtakarítás, hatékonyság I. Competito V. évf. 2. szám pp. 23-45

[5.] Hall, Robert, and Alvin E. Rabushka (1995): The Flat Tax. Stanford: Hoover Institution Press pp. 23-51.

[6.] Herich György (2007): Adótan. Penta Unió. Pécs pp 6-242

[7.] Ilonka Mária. (2004): Az adózás története az őskortól napjainkig. Budapest, Nemzeti Tankönyvkiadó. pp. 69-144

[8.] Kállai Lajos - Sztanó Imréné (2000): Adók, illetékek, járulékok és vámok. Budapest. Saldo. pp. 38-58

[9.] OECD (2006): Fundamental reform of personal income tax, tax policy studies no. 13. p.8.

[10.] Pitti Zoltán (1996): A közteherviselés intézményi rendszere Pénzügyi Szemle. 1. szám pp. 34-42.

[11.] PWC (2008): Paying Taxes 2008. Study, pp. 47-55. Letöltés helye: http://www.pwc.com/gx/en/paying-taxes/previous-editions.jhtml

[12.] Rabushka, A. E. (2006): Flat tax principles and issues, International Academic Forum on Flat Tax Rate, Centre of Excellence in Finance, Bled, Szlovénia, 2006. február 3-4.

[13.] Saavedra, P. (2007): Flat income tax reforms, Ch. 8. in Fiscal policy and economic growth, Gray, C. - Lane, T. - Varoudakis, A. (szerk.), World Bank pp. 253-280.

[14.] Semjén András (2006): A mai magyar adórendszer. Jellegzetességek, problémák, kihívások, megjelent: Előmunkálatok a társadalmi párbeszédhez, Gazdasági és Szociális Tanács, Budapest, pp 215-230 